\title{
Cannabinoid, melanocortin and opioid receptor expression on DRD1 and DRD2 subpopulations in rat striatum
}

\author{
Ralph J. A. Oude Ophuis ${ }^{1,2+}$, Arjen J. Boender ${ }^{1+}$, Andrea J. van Rozen ${ }^{1}$ and Roger A. H. Adan ${ }^{1 *}$ \\ Department of Translational Neuroscience, Brain Center Rudolf Magnus, University Medical Center Utrecht, Utrecht, Netherlands \\ ${ }^{2}$ Department of Reproductive Medicine and Gynaecology, University Medical Center Utrecht, Utrecht, Netherlands
}

\section{Edited by:}

Jose L. Lanciego, University of

Navarra, Spain

\section{Reviewed by:}

Emmanuel Valjent, Inserm, France Haiying Zhang, National Institute on Drug Abuse, USA

\section{*Correspondence:}

Roger A. H. Adan, Department of Translational Neuroscience, Brain Center Rudolf Magnus, University Medical Center Utrecht,

Universiteitsweg 100, 3584 CG

Utrecht, Netherlands

e-mail: r.a.h.adan@umcutrecht.nl

${ }^{\dagger}$ These authors have contributed equally to this work.
The striatum harbors two neuronal populations that enable action selection. One population represents the striatonigral pathway, expresses the dopamine receptor D1 (DRD1) and promotes the execution of motor programs, while the other population represents the striatopallidal pathway, expresses the dopamine receptor D2 (DRD2) and suppresses voluntary activity. The two populations integrate distinct sensorimotor, cognitive, and emotional information streams and their combined activity enables the selection of adaptive behaviors. Characterization of these populations is critical to the understanding of their role in action selection, because it aids the identification of the molecular mechanisms that separate them. To that end, we used fluorescent in situ hybridization to quantify the percentage of striatal cells that (co)express dopaminergic receptors and receptors of the cannabinoid, melanocortin or opioid neurotransmitters systems. Our main findings are that the cannabinoid 1 receptor is equally expressed on both populations with a gradient from dorsal to ventral striatum, that the opioid receptors have a preference for expression with either the DRD1 or DRD2 and that the melanocortin 4 receptor $(M C 4 R)$ is predominantly expressed in ventral parts of the striatum. In addition, we find that the level of MC4R expression determines its localization to either the DRD1 or the DRD2 population. Thereby, we provide insight into the sensitivity of the two dopaminoceptive populations to these neurotransmitters and progress the understanding of the mechanisms that enable action selection.

\section{Keywords: striatum, GPCR, opioid, cannabinoid, melanocortin, dopaminergic, FISH}

\section{INTRODUCTION}

To ensure survival, an organism needs to select adaptive behaviors from its behavioral repertoire. One neural network that is involved in action selection is the basal ganglia, which consists of several subcortical structures (Mogenson et al., 1980). The input nucleus of the basal ganglia is the striatum (Smith et al., 1994; Kincaid et al., 1998; Bolam et al., 2000), a brain area in which GABAergic projection neurons make up for more than $95 \%$ of the cellular identity (Kreitzer, 2009). These medium spiny neurons (MSNs) can be divided into two classes, based on the expression of either the dopamine receptor D1 (D1R) or the dopamine receptor D2 (D2R) (Gerfen et al., 1990; Le Moine and Bloch, 1995).

Both cellular populations influence the activity of the output nucleus of the basal ganglia; the internal globus pallidus/substantia nigra reticular part (GPi/SNpr) complex. The D1R population sends inhibitory projections to the Gpi/SNpr complex directly, while the D2Rpopulation activates the GPi/SNpr complex indirectly, via the external globus pallidus and the subthalamic nucleus (STN) (Gerfen, 1992; Kawaguchi, 1997; Gerfen and Surmeier, 2011). Activity of the GPi/SNpr is thought to exert control over voluntary movement by sending inhibitory signals to thalamic and brain stem nuclei. Much attention has been directed toward the existence of the antagonistic D1R and D2R populations that drive GPi/SNpr activity
(Alexander et al., 1986; Graybiel, 2000), because they are the physical representation of an important concept in the neurosciences: the "go-no go" pathway. In this model, the D1R population represents "go" as it inhibits the GPi/SNpr, while the D2R represents "no go" as it activates the GPi/SNpr. Activity of the D1R population is thought to promote the execution of motor programs, while activation of the $\mathrm{D} 2 \mathrm{R}$ population suppresses voluntary movement (Gerfen and Surmeier, 2011). While it is far from clear how these two populations work together to select adaptive behaviors, combined activity of these populations has been suggested to enable the execution of one particular motor program, by simultaneous suppression of competing motor programs (Mink, 2003; Cui et al., 2013).

In search of the molecular mechanisms that separate the two MSN populations and enable the selection of adaptive behaviors, the focus should not be limited to the dopaminergic system only, as dopaminergic receptors are not the only G-protein coupled receptors (GPCR) whose expression is limited to either of the two MSN populations. In addition, some neuropeptides are differentially expressed in the two MSN populations as well: D1R neurons exclusively express the acetylcholine muscarinic receptor 4 and substance P (Gerfen and Young, 1988; Bernard et al., 1992; Ince et al., 1997), while expression of the adenosine receptor $2 \mathrm{a}(\mathrm{A} 2 \mathrm{aR})$ and enkephalin is limited to the $\mathrm{D} 2 \mathrm{R}$ population (Gerfen and Young, 1988; Schiffmann et al., 1991). Moreover, it 
should be noted that the striatum can be divided into separate functional regions that process distinct information streams and are aligned to a gradient that is organized in a dorsolateral to ventromedial fashion (Voorn et al., 2004). Dorsolateral regions are primarily involved in the processing of sensorimotor information (Albin et al., 1989; Graybiel et al., 1994; Chang et al., 2002; Haber, 2003; Balleine et al., 2007; Durieux et al., 2012), central regions mediate cognitive functions such as procedural learning and working memory (Phillips and Carr, 1987; Jog et al., 1999), while ventromedial parts are associated with the integration of motivational state (Kelley and Domesick, 1982; Kelley et al., 1982; McGeorge and Faull, 1989; Cardinal et al., 2002). As separate striatal regions process different information streams, it is to be expected that they show differences in cellular identity, which could arise through the innervation of distinct neurotransmitter systems. Therefore, the location and instances of (co)expression of their receptors can serve to mark differences in cellular identity and aids the understanding of the molecular mechanisms that enable striatal functioning.

To that end, we here used fluorescent in situ hybridization (FISH) to investigate the (co)expression of dopamine receptor $\mathrm{D} 1$ (DRD1) and the dopamine receptor D2 (DRD2) mRNAs with transcripts of the GPCRs of the cannabinoid, melanocortinergic and opioid neurotransmitter systems. We quantified expression levels in five different areas, the lateral and medial caudate putamen $(\mathrm{lCPu}, \mathrm{mCPu})$, the nucleus accumbens core and shell (AccC and AccSh) and the olfactory tubercle (OT), which is thought to share functionality with the nucleus accumbens (Ikemoto, 2007). These neurotransmitter systems are known to modulate the activity of MSNs in conjunction with dopaminergic neurotransmission and visualization of their receptors might mark cellular subpopulations in the striatum. In doing so, we provide insight into the cellular architecture of the striatum and progress the understanding of its role in action selection.

\section{MATERIALS AND METHODS ANIMALS}

Adult male Wistar rats (Charles-River, Erkrath, Germany) were used $(n=2)$. The animals were housed individually $(378 \times$ $217 \times 180 \mathrm{~cm})$ in a controlled environment under a 12:12 light/dark cycle with lights on at $0700 \mathrm{~h}$. The experiments were approved by the Animal Ethics Committee of the University Medical Center Utrecht, according to Dutch legislation.

\section{FISH PROBES}

The probe sets used to detect the desired rat mRNAs are designed by Panomics (Santa Clara, USA), using published sequences (see Table 1). Blast searches were performed to avoid large homologous sequences of undesired genes and guarantee probe specificity. The probe sets consist of about 20 probe pairs, with each probe having a length of 20-25 nucleotides. The probes within each pair are designed to hybridize at adjacent regions of the target mRNA, allowing the hybridization of a preamplification oligo (Panomics) that spans the hybridized probe pair, thus ensuring signal specificity. This specific signal was further amplified by hybridization of amplification oligo's (Panomics) and visualized by label oligo's (Panomics), resulting in an amplification of up to
Table 1 | Regions and accession numbers used for synthesis of the FISH probes.

\begin{tabular}{llr}
\hline Gene & Accession number & Region \\
\hline$D R D 1$ & NM_012546 & $29-2164$ \\
$D R D 2$ & NM_012547 & $410-1488$ \\
CB1R & NM_012784 & $175-1120$ \\
MC4R & NM_013099 & $231-1136$ \\
MC3R & NM_001025270 & $198-1076$ \\
MOR & NM_013071 & $226-1228$ \\
$D O R$ & NM_012617 & $120-1095$ \\
KOR & NM_017167 & $133-1162$ \\
A2aR & NM_053294 & $504-1611$ \\
$E N K$ & NM_017139 & $21-1036$ \\
SubP & NM_012666 & $89-940$ \\
\hline
\end{tabular}

500 times for low abundant mRNAs. In addition, probe pairs were designed to hybridize at adjacent sections, covering the entire region that is mentioned in Table 1. Other probes were designed to hybridize to small regions within the desired gene sequence that share homology with undesired gene sequences. These probes did not allow hybridization of preamplification oligo's, which ensured specificity of the amplified signal.

\section{FISH PROCEDURE}

After decapitation, brains were isolated and immediately frozen on dry ice. Coronal sections $(16 \mu \mathrm{m})$ were made with a Leica CM 3050 cryostat between 1.38 and $1.70 \mathrm{~mm}$ anterior to bregma (Leica, Wetzlar, Germany). First, sections were post-fixed in 4\% paraformaldehyde for $10 \mathrm{~min}$, washed in phosphate buffered saline (PBS) and acetylated for $10 \mathrm{~min}$. After washing, sections were subsequently incubated for $2 \mathrm{~h}$ in prehybridization mix (50\% deionized formamide, $5 \times$ SSC, $5 \times$ Denhardt's solution, $250 \mu \mathrm{g} / \mathrm{ml}$ tRNA baker's yeast, $500 \mu \mathrm{g} / \mathrm{ml}$ sonicated salmon sperm DNA final concentrations in MilliQ). Next, sections were incubated overnight at $40^{\circ} \mathrm{C}$ in $120 \mu \mathrm{l}$ hybridization mix (Panomics) containing the probe sets (DRD1 1:33, DRD2 1:33, other probes 1:50) and washed. Subsequently, sections were incubated for $1.5 \mathrm{~h}$ at $40^{\circ} \mathrm{C}$ in $120 \mu \mathrm{l}$ PreAmplifier Mix (Panomics) containing preamplification oligo's (PreAmp TYPE4 1:20, PreAmp TYPE 6 1:50, PreAmp TYPE 8 1:33) and washed. Then, sections were incubated for $1.5 \mathrm{~h}$ at $40^{\circ} \mathrm{C}$ in $120 \mu \mathrm{l}$ Amplifier Mix (Panomics) containing amplification oligo's (Amp TYPE4 1:20, Amp TYPE 6 1:50, Amp TYPE 8 1:33) and washed. Next, sections were incubated for $1.5 \mathrm{~h}$ at $40^{\circ} \mathrm{C}$ in $120 \mu \mathrm{l}$ in Label Probe Mix (Panomics) containing label oligo's (LP TYPE4 1:20, LP TYPE 8 1:33, LP TYPE 6 1:50). After washing, sections were incubated in $750 \mu \mathrm{l}$ PBS supplemented with 4,6-diamidino-2-phenylindole (DAPI) $(6.7 \mu \mathrm{g} / \mathrm{ml}$, Sigma Aldrich, St. Louis, USA) for $5 \mathrm{~min}$. Finally, sections were washed and embedded in Mowiol.

\section{IMAGE ACQUISITION}

Images were obtained with a Zeiss AxioScope A1 microscope (Carl Zeiss, Jena, Germany) equipped with Chroma filter sets (Chroma, Bellows Falls, USA) and Zeiss AxioVision Rel. 4.8 acquisition software. DAPI was acquired using the 31000v2 filter 
block of Chroma. The Chroma FITC filter block 410001 was used to acquire the $488 \mathrm{~nm}$ conjugated TYPE4 label. The $550 \mathrm{~nm}$ conjugated TYPE8 label was acquired using a Chroma TRITC 41002b filter block containing a narrowband excitation filter. A custom Chroma Cy5 infrared filter was used for the acquisition of the $650 \mathrm{~nm}$ conjugated TYPE6 label. This label was excited at $650 \mathrm{~nm}$ using an HQ650/45x filter (Chroma) and light was directed by a Q680LP dichroic mirror (Chroma) through a HQ690LP emission filter (Chroma). Images were processed and analyzed using ImageJ $1.43 \mathrm{r}$ software.

\section{DATA ANALYSIS}

The (co)expression of the mRNA transcripts of the different GPCRs and neuropeptides was quantified in five different areas of the striatum: the lateral caudate putamen $(\mathrm{lCPu})$, the medial caudate putamen $(\mathrm{mCPu})$, the nucleus accumbens core (AccC), the nucleus accumbens shell (AccSh) and the olfactory tubercle (OT). Four images $(300 \times 220 \mu \mathrm{m})$ per striatal area were used for quantification of a certain mRNA with the DRD1 and DRD2 transcripts. Separate cells were identified on the basis of nuclear DAPI staining and were counted as expressing a certain mRNA if one or more fluorescent dots were present in, or in close vicinity of (defined as a circle with twice the diameter of the DAPI staining) the area of DAPI staining.

The percentage of cells expressing a certain mRNA was determined by dividing the amount of cells expressing a certain mRNA by the total amount of DAPI stained nuclei (= number of cells expressing a certain mRNA/the total number of DAPI stained nuclei*100). Statistical analyses were done by conduction of the non-parametric Kruskal-Wallis tests, with significance levels set at $\alpha=0.05$, to determine significant differences in levels of expression per striatal area in SPSS 20 for Windows (IBM, USA). The Kruskal-Wallis test was used because the small sample sizes did not allow for any inferences on the underlying distributions.

The percentage of cells expressing DRD1 mRNA and another mRNA was determined by dividing the amount of cells positive for DRD1 and another mRNA by the total amount of DRD1 positive cells (number of cells expressing DRD1 and another mRNA/total number of cells expressing $\left.D R D 1^{*} 100\right)$. An identical approach was used for calculation of the percentage of DRD2 expressing cells that also expressed another mRNA. Because of the small sample sizes, the preference for expression of a certain mRNA with transcripts of either DRD1 or DRD2 were determined by conduction of non-parametric Mann-Whitney U tests in SPSS 20 for Windows (IBM, USA). For these tests, results from separate striatal areas were combined, as individual tests for each separate striatal area would necessitate corrections for multiple comparisons and essentially yield comparable results.

To determine if cells were either high- or low-expressing, the number of fluorescent dots were counted and cells were arbitrarily classified as low expressing cells if they expressed less than 30 dots and classified as high expressing in all other instances.

\section{RESULTS}

\section{COEXPRESSION OF DRD1 AND DRD2 WITH A2aR, ENK OR SubP}

We quantified the coexpression of genes that are known to segregate to either the D1R or D2R population (see Table 2).
Table 2 | Percentage of coexpression of all investigated mRNAs with Drd1 or Drd2 transcripts.

\begin{tabular}{lcc}
\hline Gene & Expression with Drd1 (\%) & Expression with Drd2 (\%) \\
\hline A2aR & $0.39 \pm 0.15$ & $98.72 \pm 0.33$ \\
CB1R & $39.765 \pm 7.34$ & $36.66 \pm 7.07$ \\
DOR & $0.78 \pm 0.31$ & $70.27 \pm 6.30$ \\
DRD1 & $100 \pm 0.00$ & $0.14 \pm 0.01$ \\
ENK & $3.41 \pm 1.12$ & $95.27 \pm 0.93$ \\
MC3R & None observed & None observed \\
MC4R & $12.93 \pm 3.25$ & $10.94 \pm 2.45$ \\
MOR & $8.30 \pm 1.66$ & $3.70 \pm 1.01$ \\
KOR & $25.34 \pm 2.54$ & $6.38 \pm 1.19$ \\
SubP & $92.33 \pm 1.49$ & $2.32 \pm 0.51$ \\
\hline
\end{tabular}

For the D1R population, this entailed quantification of coexpression of DRD1 mRNAs with mRNAs of the precursor to substance P, protachykinin-1 (SubP). For the D2R population this entailed quantification of coexpression of DRD2 mRNAs with mRNAs of the genes $A 2 a R$ and the precursor to the opioid neuropeptide enkephalin, proenkephalin (ENK). DRD1 was virtually not expressed in any DRD2 expressing cell, as only $0.13 \pm 0.08 \%$ of DRD1 expressing cells also expressed DRD2 ( $z=-6.054, p<0.001)$ (Figures 1A,D,I, 2D and 3D). As expected, $A 2 a R$ showed a preference for coexpression with DRD2 $(z=-5.553, p<0.001$ ) (Figures 1B,C,E,F,I), as $0.39 \pm$ $0.15 \%$ of $D R D 1$ expressing cells expressed $A 2 a R$, while 98.72 $\pm 0.33 \%$ of cells positive for $D R D 1$ expressed $A 2 a R$. Specificity was also observed for expression of DRD2 with ENK $(z=$ $-5.425, p<0.001$ ) (Supplementary Figures $1 \mathrm{~A}-\mathrm{H}$ ), as only $3.41 \pm 1.12 \%$ of DRD1 cells and $95.27 \pm 0.93 \%$ of DRD2 cells expressed ENK. SubP showed a preference for colocalization with DRD1 $(z=-5.424, p<0.001)$, as $92.33 \pm 1.49 \%$ of DRD1 cells expressed SubP, while only $2.32 \pm 0.51 \%$ of DRD2 cells expressed SubP (Supplementary Figures 2A-H). DRD1, $D R D 2$, and $A 2 a R$ were expressed evenly in all striatal areas (Figures 1G,H). Finally, DRD1 was expressed in $33.75 \pm 1.02 \%$ of all striatal cells, while DRD2 was expressed in $25.17 \pm 0.82 \%$ of striatal cells, which was significantly less $(z=-4.748, p<0.001)$ (Figure 1H).

\section{COEXPRESSION OF DRD1, DRD2 AND CANNABINOID RECEPTOR 1}

Striatal areas differentially expressed mRNA transcripts of the cannabinoid receptor $1(C B 1 R)\left(\chi^{2}=11.984, d f=4, p=\right.$ $0.017)$, as the highest percentage of $C B 1 R$ positive cells was found in the $1 \mathrm{CPu}(55.05 \pm 2.61 \%)$, while lower amounts of $C B 1 R$ positive cells were observed in the other parts of the striatum (mCPU: $20.65 \pm 6.15 \%$, AccC: $12.30 \pm 1.91 \%$, AccSh: $13.85 \pm 3.17 \%$ and OT: $9.5 \pm 1.40 \%$ ), forming a decreasing dorsolateral to ventromedial gradient (Figure 2G). The CB1R showed no preference for coexpression with mRNAs of either of the two dopaminergic GPCRs, as $39.765 \pm 7.34 \%$ of DRD1 expressing cells and $36.66 \pm 7.07 \%$ of $D R D 2$ cells expressed $C B 1 R$ (Figures $2 \mathbf{A}-\mathbf{C}, \mathbf{E}, \mathbf{F}, \mathbf{H}$ ). In addition, the amount of $C B 1 R$ expression per cell was also dependent on striatal area, as high expressing cells were 

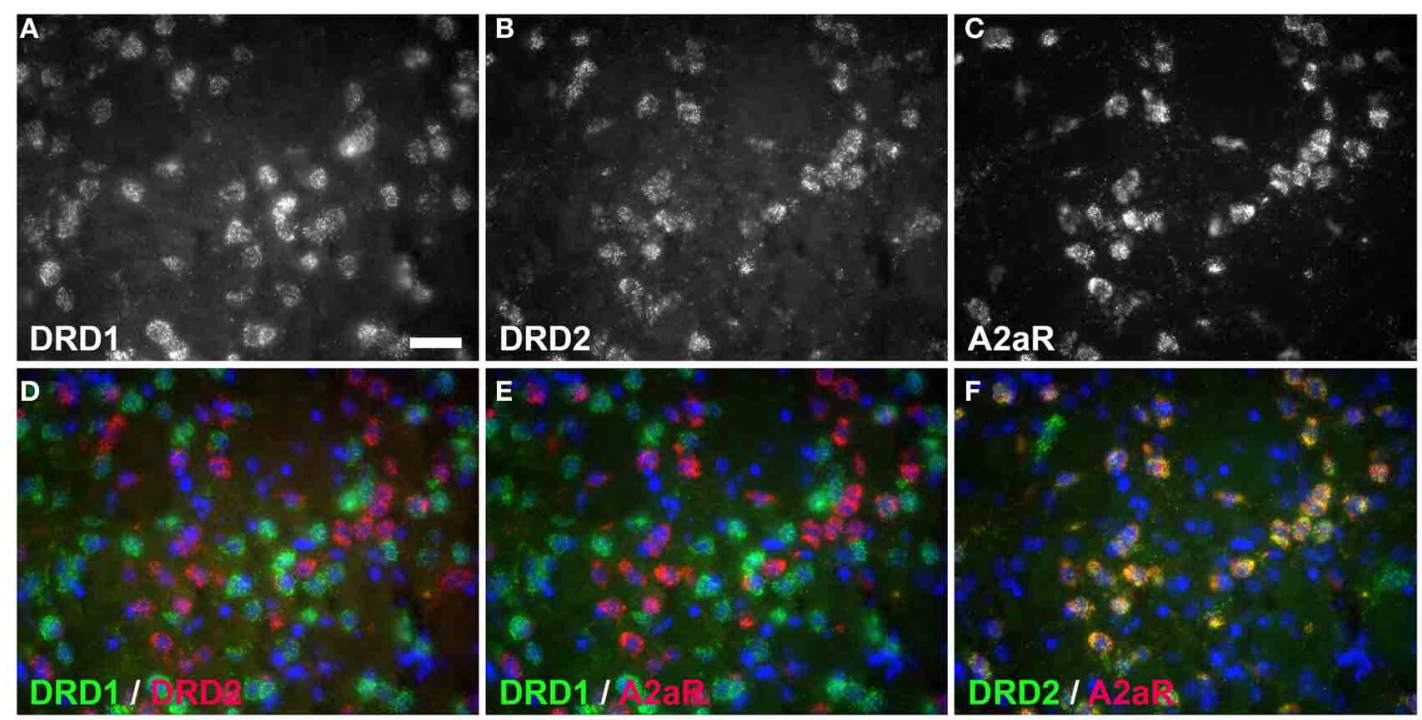

G

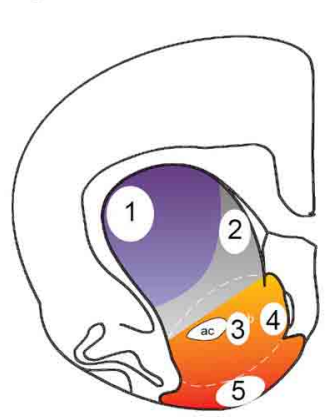

H

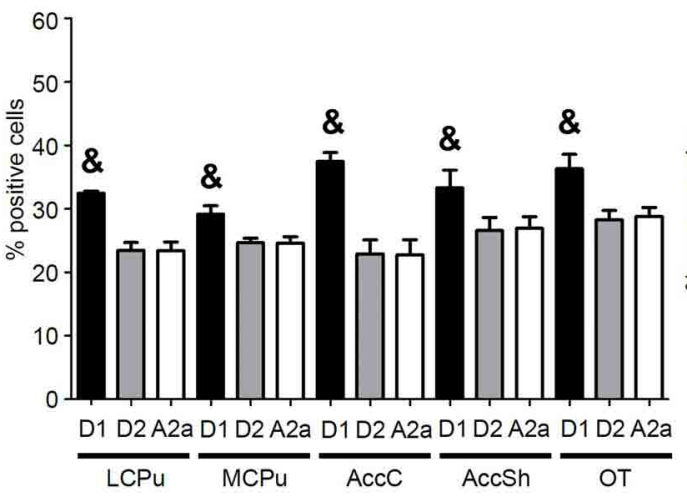

I

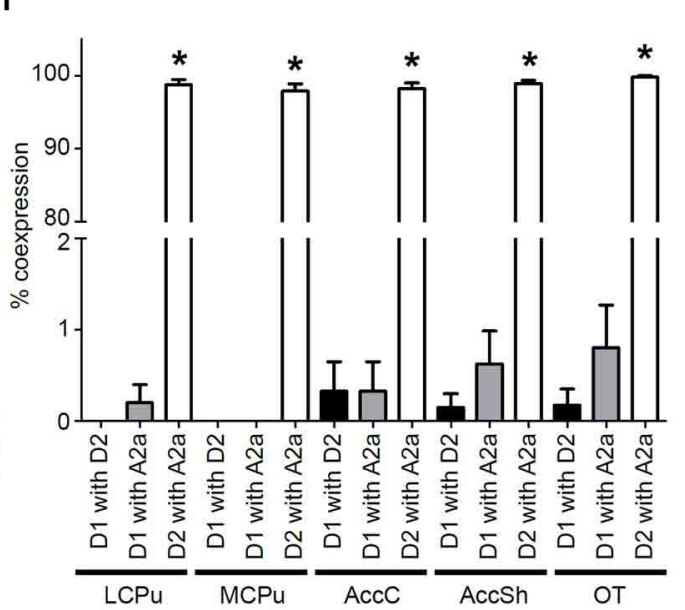

FIGURE 1 | Coexpression of the adenosine 2a receptor with both DRD1 and DRD2. (A-F) Example of staining in the lateral caudate putamen (ICPu). Nuclei were stained using 4',6-diamidino-2-phenylindole (DAPI) (blue). Clear expression for the dopamine receptor D1 (DRD1) (A), the dopamine receptor D2 (DRD2) (B) and the adenosine 2a receptor $(A 2 a R)$ (C). White bar, $25 \mu \mathrm{m}$. (D,E) Virtually no coexpression was found for $D R D 1$ and $D R D 2$ and for $D R D 1$ and $A 2 a R$. (F) Clear coexpression was found for $D R D 2$ and $A 2 a R$. (G) Quantification of expression and coexpression was performed in several regions of the striatum: $1=$ $\mathrm{ICPu}, 2$ = medial caudate putamen (mCPu), 3 = nucleus accumbens core $(\mathrm{AccC}$ ), 4 = nucleus accumbens shell (AccSh), 5 = olfactory tubercle (OT). Picture adapted from Voorn et al. (2004). (H) Quantification of the expression of DRD1, DRD2 and A2aR. Bars represent the mean percentage (+s.e.m.) of DAPI stained nuclei that are positive for DRD1, $D R D 2$ or $A 2 a R$, where "\&" indicate a significant difference of $p<0.05$ in the mean percentage of DRD1 positive cells compared to DRD2 positive cells (as determined by the Mann-Whitney $U$ test). (I) Quantification of coexpression of DRD1, DRD2, and $A 2 a R$. Bars represent the mean percentage (+s.e.m.) of cells expressing DRD1 also expressing DRD2, the percentage of DRD1 expressing cells also expressing $A 2 a R$ and the percentage of DRD2 expressing cells also expressing $A 2 a R$, where "*" indicates a significant difference of $p \leq 0.05$ in the percentage of cells that coexpress $D R D 1$ and $A 2 a R$ compared to cells that coexpress $D R D 2$ and $A 2 a R$ (as determined by the Mann-Whitney $U$ test). predominantly found in the $\mathrm{lCPu}$ and low expressing cells in other parts of the striatum (Figures 2I-M). Also here, the DRD1 and DRD2 populations were segregated, as we found that only $0.20 \pm 0.07 \%$ of $D R D 1$ expressing cells also expressed DRD2 $(z=-5.929, p<0.001)$ (Figure 2H). Moreover, significantly more striatal cells expressed DRD1 $(34.91 \pm 1.24 \%)$ than DRD2 $(23.17 \pm 0.84 \%)(z=-5.195, p<$ 0.001) (Figure 2G).

\section{COEXPRESSION OF DRD1 AND DRD2 WITH MELANOCORTIN RECEPTORS}

No mRNA expression of the melanocortin receptor 3 (MC3R) was found (Supplementary Figure 3), but a clear signal was present for mRNAs of the melanocortin receptor 4 (MC4R) (Figure 3C) and $M C 4 R$ was differentially expressed in striatal areas $\left(\chi^{2}=17.361\right.$, $d f=4, p=0.002)$. The highest expression was found in the OT $(21.43 \pm 3.84 \%)$, when compared to the AccC $(8.30 \pm 1.83 \%)$ 


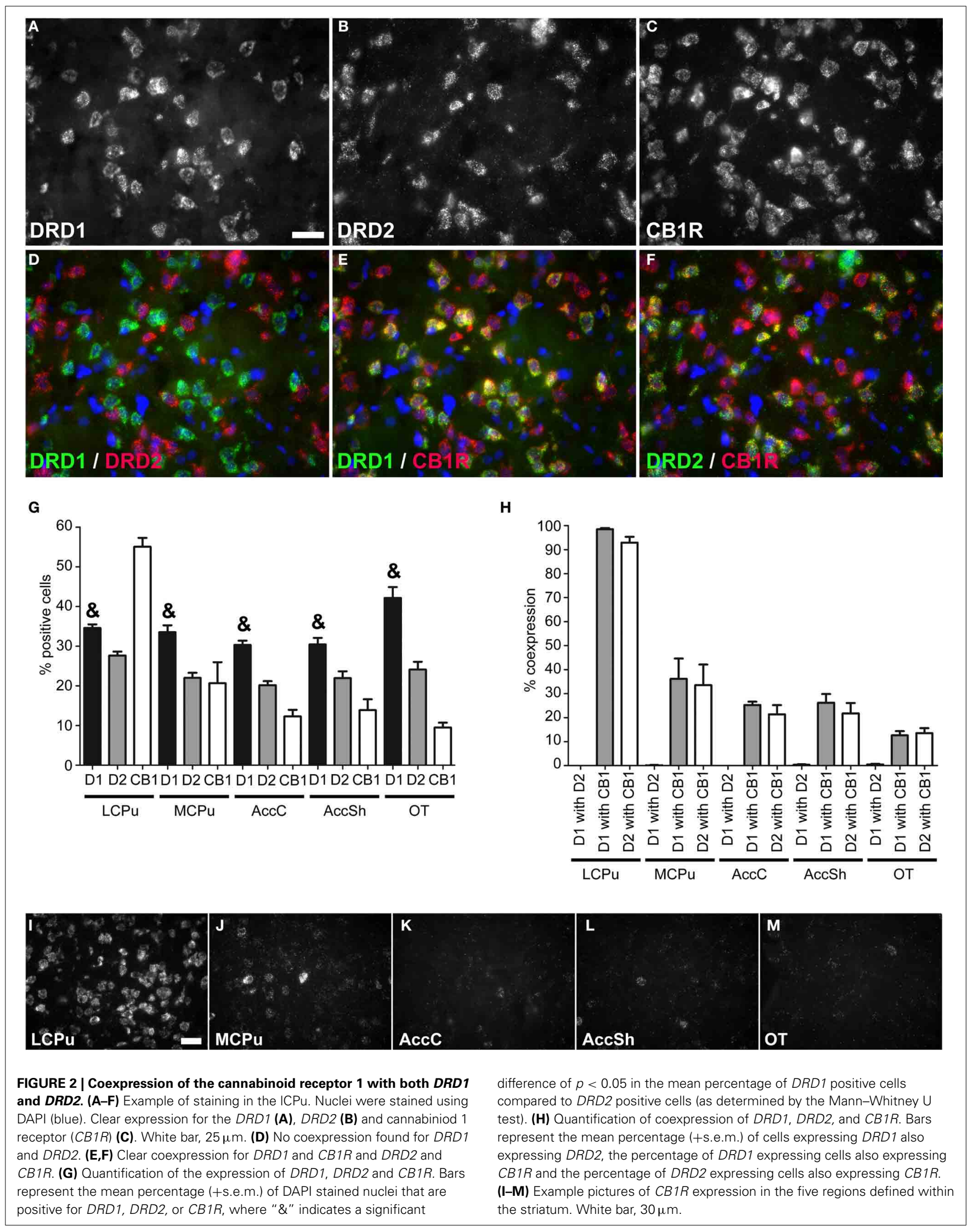


and AccSh (5.68 $\pm 1.63 \%)$. No MC4R expression was observed in the $\mathrm{mCPu}$ and virtually no expression in the $\mathrm{lCPu}(0.43 \pm 0.24 \%)$, so MC4R mRNA expression gradually decreases ventral to dorsal parts of the striatum (Figures 3G,I-M). The $M C 4 R$ showed no apparent preference for either dopaminergic GPCR, as $12.93 \pm$ $3.25 \%$ of DRD1 expressing cells and $10.94 \pm 2.45 \%$ of DRD2 expressed MC4R (Figures 3A-C,E,F,H), although it was observed that cells expressing high levels of $M C 4 R$ also expressed DRD1, but not DRD2 (Figures $3 \mathbf{N}-\mathbf{R}$ ). Again, the DRD1 and DRD2 populations were segregated, as $0.14 \pm 0.08 \%$ of $D R D 1$ expressing cells also expressed DRD2 $(z=-6.054, p<0.001)$ (Figure 3H). In addition, striatal cells expressed significantly more DRD1 $(34.35 \pm 1.39 \%)$ than DRD2 $(20.23 \pm 1.03 \%)(z=-5.384$, $p<0.001$ ) (Figure 3G).

\section{COEXPRESSION OF DRD1 AND DRD2 WITH OPIOID RECEPTORS}

Also mRNA transcripts of the $\mu$-opioid receptor $(M O R)$ were differentially expressed within the striatum (lCPu: $1.225 \pm 0.82 \%$, mCPu: $3.45 \pm 0.82 \%$, AccC: $6.375 \pm 1.99 \%$, AccSh: $4.95 \pm 1.28 \%$ and OT: $1.9 \pm 0.85 \%)\left(\chi^{2}=10.928, d f=4, p=0.027\right)$ (Figure 4G). MOR showed a preference for expression with the DRD1, as $8.30 \pm 1.66 \%$ of $D R D 1$ expressing cells and $3.70 \pm 1.01 \%$ of DRD2 expressing cells also expressed MOR $(z=-2.112, p=0.035)$ (Figures 4A,D,H). Transcripts of the $\delta$-opioid receptor $(D O R)$ were dispersed evenly in striatal areas (lCPu: $15.55 \pm 4.81 \%, \mathrm{mCPu}: 17.03 \pm 5.47 \%$, AccC: $13.33 \pm$ $3.91 \%$, AccSh: $18.63 \pm 5.78 \%$ and OT: $25.85 \pm 4.37 \%$ ) (Figure 4I). DOR showed a preference for expression with DRD2, as $0.78 \pm 0.31 \%$ of DRD1 expressing cells and $70.27 \pm 6.30 \%$ of DRD2 expressing cells also expressed DOR $(z=-5.530$, $p<0.001$ ) (Figures 4B,E,J). Transcripts of the $\kappa$-opioid receptor $(K O R)$ positive cells were differentially expressed in the striatum (lCPu: $5.175 \pm 1.07 \%, \mathrm{mCPu}: 7.93 \pm 1.69 \%$, AccC: $10.90 \pm 1.85 \%$, AccSh: $14.18 \pm 2.60 \%$ and OT: $14.85 \pm 3.36 \%)$ $\left(\chi^{2}=10.928, d f=4, p=0.027\right)$, showing a gradual increase in expression from dorsolateral to ventromedial parts of the striatum (Figure 4K). Moreover, KOR showed a preference for expression with the DRD1, as $25.34 \pm 2.54 \%$ of $D R D 1$ expressing cells and $6.38 \pm 1.19 \%$ of $D R D 2$ expressing cells expressed $K O R$ as well $(z=-4.951, p<0.001)$ (Figures 4C,F,L). Also here, the DRD1 and $D R D 2$ populations were segregated, as $0.13 \pm 0.04 \%$ of $D R D 1$ expressing cells also expressed DRD2 $(z=-7.554, p<0.001)$ (Figure 3H). In addition, striatal cells did express significantly more DRD1 $(34.35 \pm 1.39 \%)$ than DRD2 $(20.23 \pm 1.03 \%)$ $(z=-5.384, p<0.001)$ (Figure 3G).

\section{DISCUSSION}

To the best of our knowledge, we here show for the first time which percentage of striatal cells express DRD1 and DRD2 mRNAs and transcripts of the cannabinoid, melanocortin or opioid receptors. We first investigated if the expression of genes that are known to be expressed in only one of the two MSN populations indeed segregate along these lines. The D1R population is known to express SubP, while the D2R population can be identified by expression of ENK (Gerfen and Young, 1988). Moreover, $\mathrm{A} 2 \mathrm{aR}$ is known to inhibit the function of the $\mathrm{D} 2 \mathrm{R}$ by the formation of a functional heterodimer (Canals et al., 2003; Azdad et al., 2009), for which coexpression is a prerequisite (Schiffmann et al., 1991). Indeed, we observed near specific coexpression of the transcripts of SubP with DRD1 mRNAs and of ENK and $A 2 a R$ transcripts with $D R D 2$ mRNAs.and found very few cells $(<1 \%$ ) expressing both DRD1 and DRD2. In addition, we found that striatal cells express DRD1 in higher percentages than DRD2, which confirmed earlier findings (Bertran-Gonzalez et al., 2008; Matamales et al., 2009; Gangarossa et al., 2013b).

As stated earlier, a clear distinction in dopaminergic GPCR expressing populations can be made based on the expression patterns of either the D1R or the D2R (Gerfen et al., 1990; Le Moine and Bloch, 1995). However, this clear segregation of the D1R and D2R populations has been subject of much debate (BertranGonzalez et al., 2010), as a number of groups have reported DRD1 and DRD2 coexpressing cells and the existence of functional D1R/D2R heterodimers (Larson and Ariano, 1994; Shetreat et al., 1996; Aizman et al., 2000; Hasbi et al., 2009; Perreault et al., 2012). These studies should be interpreted with care however, as the use of striatal cultures, in which neurons are functioning in an artificial environment, as well as cross-reactivity of the used antibodies may explain the reported D1R/D2R heterodimers, In any case, we also found instances of $D R D 1$ and $D R D 2$ coexpression, in percentages similar to studies using BAC transgenic mice (Gangarossa et al., 2013b). Moreover, a small overlap of the D1R and D2R populations is also evidenced by our finding that the neuropeptides $E N K$ and SubP are expressed in both MSN populations. In addition, a recent study suggests that an area between the AccSh and AccC is an ideal anatomical substrate where D1R/D2R signaling could take place (Gangarossa et al., 2013a). So, MSNs might not be completely segregated into a D1R/SubP population and a D2R/ENK/A2aR population, depending on striatal area. Future research has to show if and where the two MSN populations overlap and establish the functional consequences of this presumed overlap.

Our next focus was on the expression of $C B 1 R$ in the two MSN populations. $C B 1 R$ mRNA was highly expressed in the dorsolateral part of the striatum and its expression decreased toward ventromedial parts of the striatum, in congruence with earlier reports (Hermann et al., 2002; Martin et al., 2008). Extending on these results, we found that the $C B 1 R$ is promiscuous in its coexpression with the dopaminergic GPCRs and that nearly all $D R D 1$ and DRD2 positive neurons expressed the $C B 1 R$ in the $1 C P u$, while this percentage was much lower in the ventral striatum. Despite the lower expression of $C B 1 R$ in the ventral parts of the striatum, our findings stress the ability of endocannabinoids to influence both motor functions and reward processing (Monory et al., 2007; Ferre et al., 2010). Moreover, our data confirm results of earlier studies that showed that the cannabinoid system is able to give local feedback on the activity of both MSN populations (for extensive review see: Fitzgerald et al., 2012)

The melanocortinergic system is well known for its role in the regulation of energy balance, in particular through the action on its two centrally expressed GPCRs: the MC3R and the MC4R (Gantz and Fong, 2003). No indication of striatal expression of $M C 3 R$ transcripts was found, readily excluding a prominent role for $M C 3 R$ signaling in the striatum. Our observations suggest that the melanocortinergic system primarily interacts with ventral 

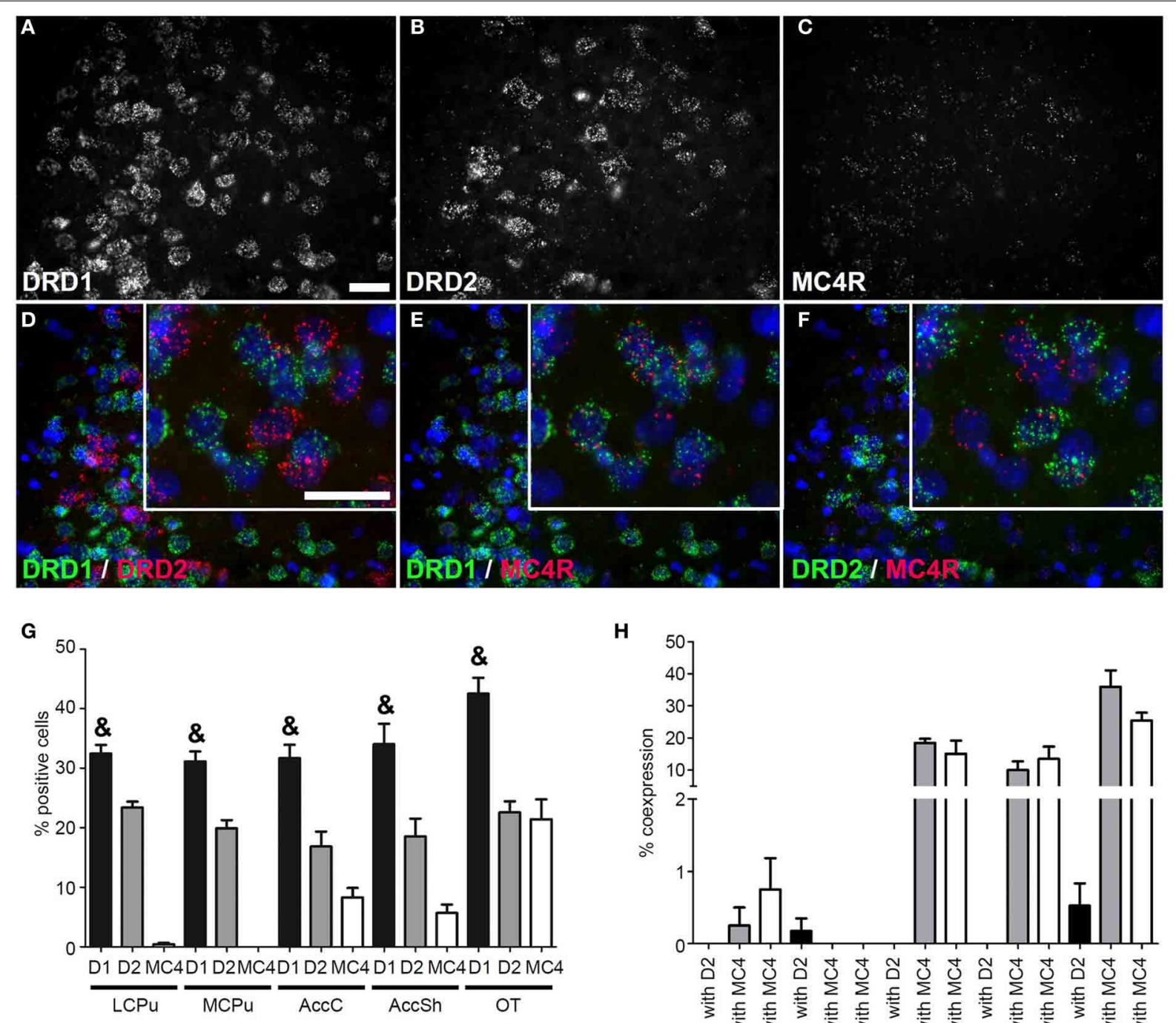

H
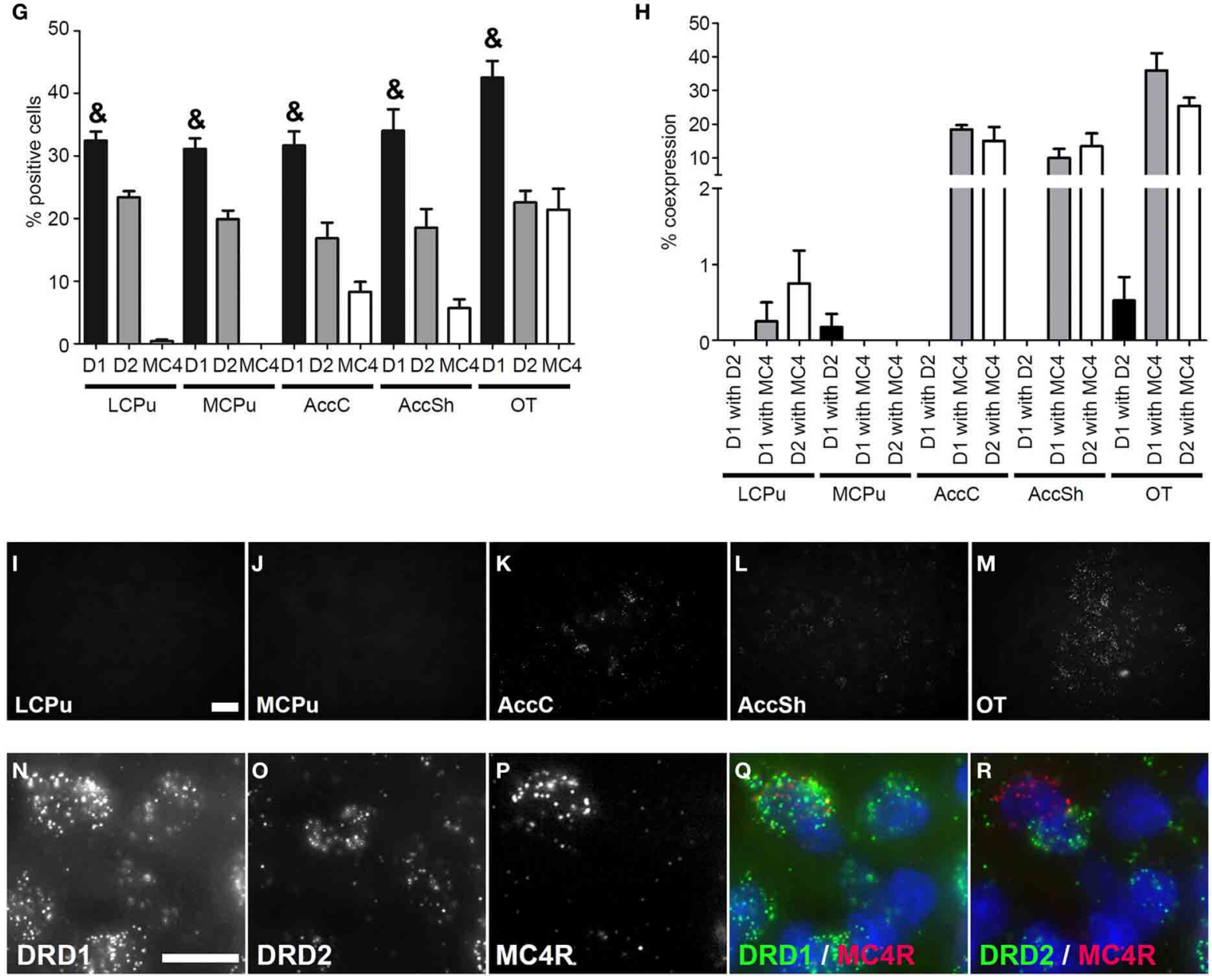

FIGURE 3 | Coexpression of the melanocortin 4 receptor with both DRD1 and DRD2. (A-F) Example of staining in the OT. Nuclei were stained using DAPI (blue). Clear expression for the DRD1 (A), DRD2 (B), and modest expression for melanocortin 4 receptor (MC4R) (C). Enlargements of cells are depicted expressing both DRD1 and MC4R, or both DRD2 and MC4R. White bar, $25 \mu \mathrm{m}$. (D) No coexpression found for DRD1 and DRD2. (E,F) Clear coexpression for DRD1 and $M C 4 R$ and DRD2 and MC4R. White bar, $25 \mu \mathrm{m}$. (G) Quantification of the expression of $D R D 1, D R D 2$, and $M C 4 R$. Bars

(Continued) 


\section{FIGURE 3 | Continued}

represent the mean percentage + s.e.m. of DAPI stained nuclei that are positive for $D R D 1, D R D 2$, or MC4R, where "\&" indicates a significant difference of $p<0.05$ in the mean percentage of $D R D 1$ positive cells compared to DRD2 positive cells (as determined by the Mann-Whitney $U$ test). (H) Quantification of coexpression of DRD1, DRD2, and MC4R. Bars represent the mean percentage (+s.e.m.) of cells expressing DRD1 also expressing $D R D 2$, the percentage of $D R D 1$ expressing cells also expressing $M C 4 R$ and the percentage of DRD2 expressing cells also expressing MC4R. (I-M) Example pictures of MC4R expression in the five regions defined within the striatum. White bar, $30 \mu \mathrm{m}$. (N-R) Cells expressing high amounts of MC4R are found in the DRD1 population. White bar, $10 \mu \mathrm{m}$. parts of the striatum. Looking at the percentage of coexpression of $M C 4 R$ transcripts with either DRD1 or DRD2 transcripts, no significant differences were observed. However, the expression levels of MC4R transcripts correlate with the expression of either the $D R D 1$ or the DRD2, as high levels of $M C 4 R$ transcripts coincide with coexpression of DRD1, but not DRD2 mRNAs. This correlation is of particular interest in light of a number of studies that reported the involvement of MC4Rs expressed on D1R MSNs in a range of behavioral phenotypes. Lim et al. have found that the MC4R mediates stress-induced decreases in the strength of excitatory synapses onto D1R, but not D2R expressing MSNs, as the MC4R is necessary to internalize AMPA receptors on D1R MSNs after chronic stress (Lim et al., 2012). Moreover, MC4Rs expressed on D1R MSNs mediate parts of the phenotype observed in MC4R null mice, such as increased meal size, insensitivity to cocaineinduced anorexia and locomotor sensitization and the inability to be conditioned for high-fat food reinforcers (Cui et al., 2012; Cui and Lutter, 2013). In addition, the high expression of MC4R on D1R MSNs could explain why the infusion of MC4R antagonists blocks the behavioral effects of cocaine, which are thought to be mediated primarily by D1R signaling (Hsu et al., 2005). Taken together, these findings indicate that MC4R signaling strongly modulates D1R signaling, making it an interesting target for pharmacotherapies to combat psychopathologies such as addiction and obesity.

Opioids generally act upon three different GPCRs. These GPCRs differ in opioid affinity and are expressed throughout the entire striatum (Mansour et al., 1995). We and others observed high $M O R$ mRNA expression in the AccC and AccSh, implying a stronger influence of $M O R$ on the nucleus accumbens. Moreover, we confirmed a gradual increase in the expression of $K O R$ transcripts from dorsolateral toward ventromedial parts of the striatum (Mansour et al., 1994) and showed that all investigated opioid receptors show a preference for expression with either of the to dopaminergic GPCRs: the DOR showed near exclusive coexpression with the DRD2, the KOR showed a preference for coexpression with the $D R D 1$, and the MOR showed a preference for coexpression with the DRD1.

The main agonist for DOR is enkephalin, for KOR dynorphin and for MOR endorphin (Corbett et al., 2006). Dynorphins and enkephalins are synthesized in DRD1 and DRD2 expressing neurons, respectively, (Gerfen et al., 1990), while endorphins are synthesized in POMC expressing neurons (Corbett et al., 2006). These observations led us to postulate that dynorphins and enkephalins are able to give selective feedback on DRD1 and DRD2 expressing neurons, respectively. Since opioid receptors signal via Gi resulting in hyperpolarization via activation of GIRK channels (Torrecilla et al., 2002), release of opioids from striatal MSNs may provide an auto-inhibitory feedback loop.
KOR activation has been associated with dysphoria and aversion (Pfeiffer et al., 1986; Shippenberg et al., 2001), while DOR activation has been suggested to improve negative emotional states (Filliol et al., 2000; Ragnauth et al., 2001; Roberts et al., 2001; Perrine et al., 2006). Also, activation of DOR increases the release of dopamine in the striatum (Di Chiara and Imperato, 1988), while KOR activation has the opposite effect (Mulder et al., 1984). These opposing roles are also reflected in the differential influence of these opioid receptors on dopamine-related behaviors (Shippenberg and Herz, 1987; Bals-Kubik et al., 1989). It is tempting to speculate that this is due to the preference of these receptors for one of the two MSN populations, but our results are not congruent with results of others, which found DRD1 to coexpress with DOR in much higher levels than we did (Ambrose et al., 2006). This might be due to differences in subcellular localization at the pre- or post-synapse, to internalization of the receptor, to the striatal region that was under investigation in the other study (a specific part of the dorsal striatum) or to cross-reactivity of the antibodies used and future studies will have to clarify this discrepancy. Taken together, our observations suggest that MOR is able to modulate the activity of both MSN populations, with a stronger influence on the DRD1 population, as opposed to DOR and KOR, which seem to target specific MSN subpopulations.

Although through the quantification of the percentage of striatal cells that express DRD1 and DRD2 mRNAs with transcripts of cannabinoid, melanocortin or opioid GPCRs this study provides valuable insight in the cellular architecture of the striatum, it has two major limitations that should be taken into account. Firstly, the nature of our methods do not allow for any inference on the location of the proteins that are translated from the GPCR mRNAs. As such, we cannot distinguish between pre- and postsynaptically located GPCRs and thus do not provide the exact location where endocannabinoids, melanocortins, and opioids act to modulate MSN activity. Secondly, we only used hemispheres of two different animals in this study. As the majority of our results are so prominent (the GPCRs under investigation showed either a clear preference for colocalization with the DRD1 or DRD2 or not), we could not justify increasing the amount of animals because of ethical reasons.

In sum, the present data indicate that the dopaminergic, cannabinoid, and opioid systems exert control over the entire striatum, while the melanocortinergic system specifically targets the ventral parts. Moreover, we find that the opioid GPCRs have a preference for expression with either the DRD1 or DRD2 and that high and low levels of $M C 4 R$ expression imply coexpression with DRD1 and DRD2, respectively. Hereby, we expand the list of GPCRs that are preferentially expressed in one of the MSN populations and offer some understanding of the molecular mechanisms that enable the selection of adaptive behaviors. 


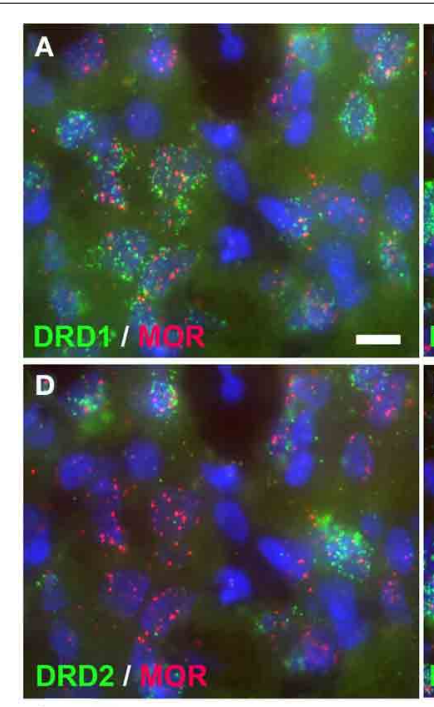

G
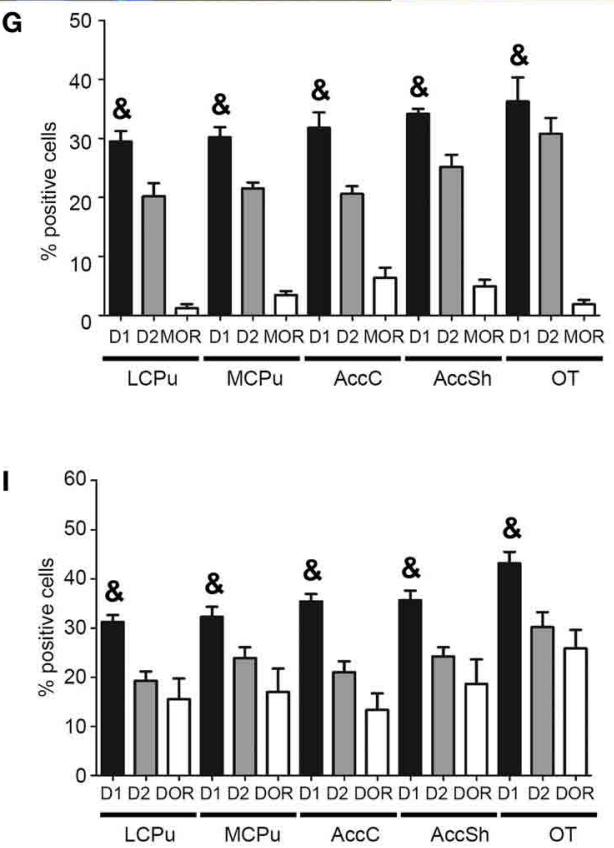

K

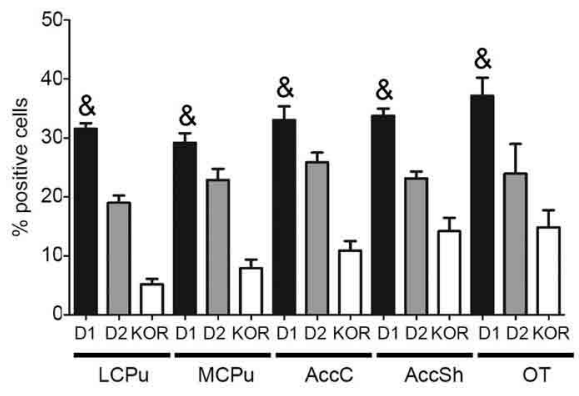

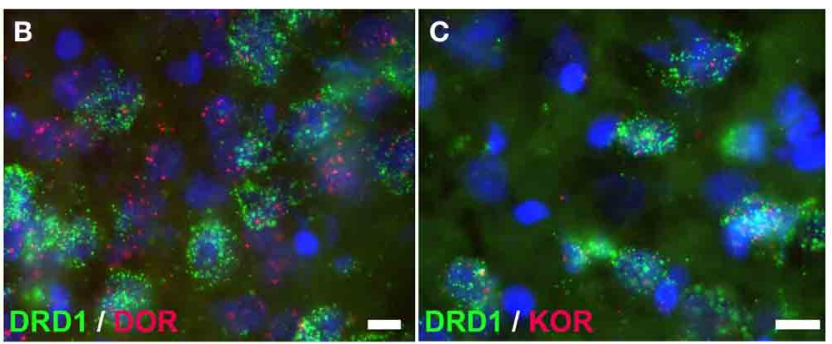
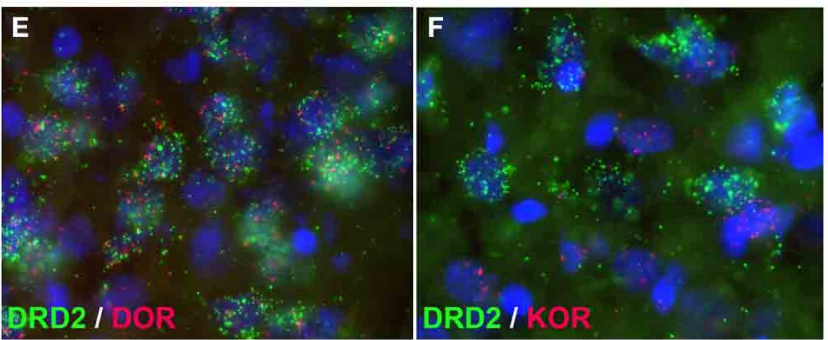

H 30

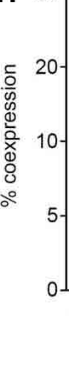

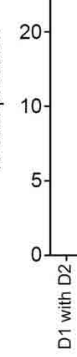

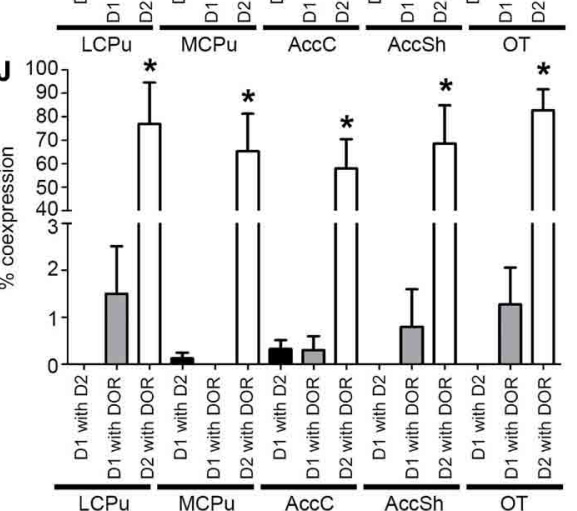

L

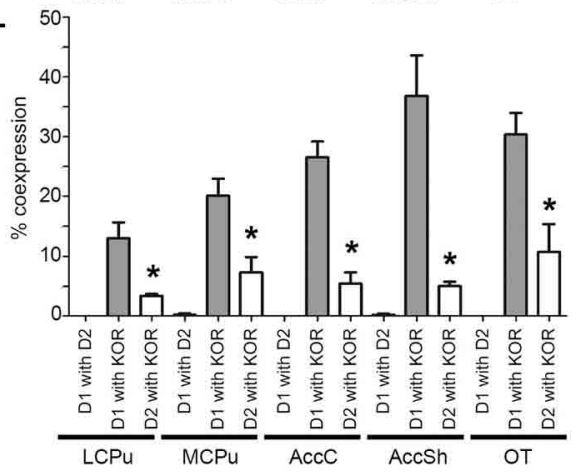

delta-opioid receptor (DOR), none found for DRD1 and DOR. (C,F) Coexpression for DRD1 and kappa-opioid receptor $(K O R)$, and some coexpression for $D R D 2$ and $K O R$. $(\mathbf{G}, \mathbf{I}, \mathbf{K})$ Quantification of coexpression of DRD1, DRD2, MOR, DOR and KOR. Bars

(Continued) 


\section{FIGURE 4 | Continued}

represent the mean percentage (+s.e.m.) of DAPI stained nuclei that are positive for $D R D 1, D R D 2, M O R, D O R$, or $K O R$, where " $\&$ " indicates a significant difference of $p<0.05$ in the mean percentage of $D R D 1$ positive cells compared to $D R D 2$ positive cells (as determined by the Mann-Whitney $\mathrm{U}$ test). (H,J,L) Quantification of coexpression of DRD1 or DRD2 and MOR, $D O R$, or $K O R$. Bars represent the mean percentage (+s.e.m.) of cells expressing $D R D 1$ also expressing $D R D 2$, the percentage of $D R D 1$ expressing cells also expressing $M O R, D O R$, or $K O R$ and the percentage of DRD2 expressing cells also expressing MOR, DOR, or KOR, where "*" indicate significant differences of $p \leq 0.05$ in the percentage of cells that coexpress $D R D 1$ and $M O R, D O R$ or KOR compared to cells that coexpress DRD2 and MOR, DOR, or KOR (as determined by the Mann-Whitney U test).

\section{ACKNOWLEDGMENTS}

We would like to thank Dr. Jean-Luc Paquet (Abbott Healthcare, Frounier Laboratoires, Daix), for providing reagents and training of the Quantigene ViewRNA ISH cell assay. These studies were supported by TI Pharma, project D1-105.

\section{SUPPLEMENTARY MATERIAL}

The Supplementary Material for this article can be found online at: http://journal.frontiersin.org/journal/10.3389/fnana. 2014.00014/abstract

\section{REFERENCES}

Aizman, O., Brismar, H., Uhlen, P., Zettergren, E., Levey, A. I., Forssberg, H., et al. (2000). Anatomical and physiological evidence for D1 and D2 dopamine receptor colocalization in neostriatal neurons. Nat. Neurosci. 3, 226-230. doi: $10.1038 / 72929$

Albin, R. L., Young, A. B., and Penney, J. B. (1989). The functional anatomy of basal ganglia disorders. Trends Neurosci. 12, 366-375. doi: 10.1016/01662236(89)90074-X

Alexander, G. E., Delong, M. R., and Strick, P. L. (1986). Parallel organization of functionally segregated circuits linking basal ganglia and cortex. Annu. Rev. Neurosci. 9, 357-381. doi: 10.1146/annurev.ne.09.030186.002041

Ambrose, L. M., Gallagher, S. M., Unterwald, E. M., and Van Bockstaele, E. J. (2006). Dopamine-D1 and delta-opioid receptors co-exist in rat striatal neurons. Neurosci. Lett. 399, 191-196. doi: 10.1016/j.neulet.2006. 02.027

Azdad, K., Gall, D., Woods, A. S., Ledent, C., Ferre, S., and Schiffmann, S. N. (2009). Dopamine D2 and adenosine A2A receptors regulate NMDA-mediated excitation in accumbens neurons through A2A-D2 receptor heteromerization. Neuropsychopharmacology 34, 972-986. doi: 10.1038/npp.2008.144

Balleine, B. W., Delgado, M. R., and Hikosaka, O. (2007). The role of the dorsal striatum in reward and decision-making. J. Neurosci. 27, 8161-8165. doi: 10.1523/JNEUROSCI.1554-07.2007

Bals-Kubik, R., Herz, A., and Shippenberg, T. S. (1989). Evidence that the aversive effects of opioid antagonists and kappa-agonists are centrally mediated. Psychopharmacology (Berl). 98, 203-206. doi: 10.1007/BF00444692

Bernard, V., Normand, E., and Bloch, B. (1992). Phenotypical characterization of the rat striatal neurons expressing muscarinic receptor genes. J. Neurosci. 12, 3591-3600.

Bertran-Gonzalez, J., Bosch, C., Maroteaux, M., Matamales, M., Herve, D., Valjent, E., et al. (2008). Opposing patterns of signaling activation in dopamine D1 and D2 receptor-expressing striatal neurons in response to cocaine and haloperidol. J. Neurosci. 28, 5671-5685. doi: 10.1523/JNEUROSCI.1039-08. 2008

Bertran-Gonzalez, J., Herve, D., Girault, J. A., and Valjent, E. (2010). What is the degree of segregation between striatonigral and striatopallidal projections? Front. Neuroanat. 4:136. doi: 10.3389/fnana.2010.00136

Bolam, J. P., Hanley, J. J., Booth, P. A., and Bevan, M. D. (2000). Synaptic organisation of the basal ganglia. J. Anat. 196(pt 4), 527-542. doi: 10.1046/j.14697580.2000.19640527.x

Canals, M., Marcellino, D., Fanelli, F., Ciruela, F., De Benedetti, P., Goldberg, S. R., et al. (2003). Adenosine A2A-dopamine D2 receptor-receptor heteromerization: qualitative and quantitative assessment by fluorescence and bioluminescence energy transfer. J. Biol. Chem. 278, 46741-46749. doi: 10.1074/jbc.M3064 51200

Cardinal, R. N., Parkinson, J. A., Hall, J., and Everitt, B. J. (2002). Emotion and motivation: the role of the amygdala, ventral striatum, and prefrontal cortex. Neurosci. Biobehav. Rev. 26, 321-352. doi: 10.1016/S0149-7634(02) 00007-6

Chang, J. Y., Chen, L., Luo, F., Shi, L. H., and Woodward, D. J. (2002). Neuronal responses in the frontal cortico-basal ganglia system during delayed matchingto-sample task: ensemble recording in freely moving rats. Exp. Brain Res. 142, 67-80. doi: 10.1007/s00221-001-0918-3

Corbett, A. D., Henderson, G., McKnight, A. T., and Paterson, S. J. (2006). 75 years of opioid research: the exciting but vain quest for the Holy Grail. Br. J. Pharmacol. 147(Suppl. 1), S153-S162. doi: 10.1038/sj.bjp.07 06435

Cui, G., Jun, S. B., Jin, X., Pham, M. D., Vogel, S. S., Lovinger, D. M., et al. (2013). Concurrent activation of striatal direct and indirect pathways during action initiation. Nature 494, 238-242. doi: 10.1038/nature11846

Cui, H., and Lutter, M. (2013). The expression of MC4Rs in D1R neurons regulates food intake and locomotor sensitization to cocaine. Genes Brain Behav. 12, 658-665. doi: 10.1111/gbb.12057

Cui, H., Mason, B. L., Lee, C., Nishi, A., Elmquist, J. K., and Lutter, M. (2012). Melanocortin 4 receptor signaling in dopamine 1 receptor neurons is required for procedural memory learning. Physiol. Behav. 106, 201-210. doi: 10.1016/j.physbeh.2012.01.025

Di Chiara, G., and Imperato, A. (1988). Opposite effects of mu and kappa opiate agonists on dopamine release in the nucleus accumbens and in the dorsal caudate of freely moving rats. J. Pharmacol. Exp. Ther. 244, 1067-1080.

Durieux, P. F., Schiffmann, S. N., and De Kerchove D'Exaerde, A. (2012). Differential regulation of motor control and response to dopaminergic drugs by D1R and D2R neurons in distinct dorsal striatum subregions. EMBO J. 31, 640-653. doi: 10.1038/emboj.2011.400

Ferre, S., Lluis, C., Justinova, Z., Quiroz, C., Orru, M., Navarro, G., et al. (2010). Adenosine-cannabinoid receptor interactions. Implications for striatal function. Br. J. Pharmacol. 160, 443-453. doi: 10.1111/j.1476-5381.2010.00 723.x

Filliol, D., Ghozland, S., Chluba, J., Martin, M., Matthes, H. W., Simonin, F., et al. (2000). Mice deficient for delta- and mu-opioid receptors exhibit opposing alterations of emotional responses. Nat. Genet. 25, 195-200. doi: 10.1038/ 76061

Fitzgerald, M. L., Shobin, E., and Pickel, V. M. (2012). Cannabinoid modulation of the dopaminergic circuitry: implications for limbic and striatal output. Prog. Neuropsychopharmacol. Biol. Psychiatry 38, 21-29. doi: 10.1016/j.pnpbp.2011.12.004

Gangarossa, G., Espallergues, J., De Kerchove D’Exaerde, A., El Mestikawy, S., Gerfen, C. R., Herve, D., et al. (2013a). Distribution and compartmental organization of GABAergic medium-sized spiny neurons in the mouse nucleus accumbens. Front. Neural Circuits 7:22. doi: 10.3389/fncir.2013. 00022

Gangarossa, G., Espallergues, J., Mailly, P., De Bundel, D., De Kerchove D’Exaerde, A., Herve, D., et al. (2013b). Spatial distribution of D1R- and D2R-expressing medium-sized spiny neurons differs along the rostro-caudal axis of the mouse dorsal striatum. Front. Neural Circuits 7:124. doi: 10.3389/fncir.2013. 00124

Gantz, I., and Fong, T. M. (2003). The melanocortin system. Am. J. Physiol. Endocrinol. Metab. 284, E468-E474. doi: 10.1152/ajpendo.00434.2002

Gerfen, C. R. (1992). The neostriatal mosaic: multiple levels of compartmental organization in the basal ganglia. Annu. Rev. Neurosci. 15, 285-320. doi: 10.1146/annurev.ne.15.030192.001441

Gerfen, C. R., Engber, T. M., Mahan, L. C., Susel, Z., Chase, T. N., Monsma, F. J., et al. (1990). D1 and D2 dopamine receptor-regulated gene expression of striatonigral and striatopallidal neurons. Science 250, 1429-1432. doi: $10.1126 /$ science. 2147780 
Gerfen, C. R., and Surmeier, D. J. (2011). Modulation of striatal projection systems by dopamine. Annu. Rev. Neurosci. 34, 441-466. doi: 10.1146/annurev-neuro061010-113641

Gerfen, C. R., and Young, W. S. 3rd (1988). Distribution of striatonigral and striatopallidal peptidergic neurons in both patch and matrix compartments: an in situ hybridization histochemistry and fluorescent retrograde tracing study. Brain Res. 460, 161-167. doi: 10.1016/0006-8993(88)91217-6

Graybiel, A. M. (2000). The basal ganglia. Curr. Biol. 10, R509-R511. doi: 10.1016/S0960-9822(00)00593-5

Graybiel, A. M., Aosaki, T., Flaherty, A. W., and Kimura, M. (1994). The basal ganglia and adaptive motor control. Science 265, 1826-1831. doi: 10.1126/science. 8091209

Haber, S. N. (2003). The primate basal ganglia: parallel and integrative networks. J. Chem. Neuroanat. 26, 317-330. doi: 10.1016/j.jchemneu.2003.10.003

Hasbi, A., Fan, T., Alijaniaram, M., Nguyen, T., Perreault, M. L., O’Dowd, B. F., et al. (2009). Calcium signaling cascade links dopamine D1-D2 receptor heteromer to striatal BDNF production and neuronal growth. Proc. Natl. Acad. Sci. U.S.A. 106, 21377-21382. doi: 10.1073/pnas.0903676106

Hermann, H., Marsicano, G., and Lutz, B. (2002). Coexpression of the cannabinoid receptor type 1 with dopamine and serotonin receptors in distinct neuronal subpopulations of the adult mouse forebrain. Neuroscience 109, 451-460. doi: 10.1016/S0306-4522(01)00509-7

Hsu, R., Taylor, J. R., Newton, S. S., Alvaro, J. D., Haile, C., Han, G., et al. (2005). Blockade of melanocortin transmission inhibits cocaine reward. Eur. J. Neurosci. 21, 2233-2242. doi: 10.1111/j.1460-9568.2005.04038.x

Ikemoto, S. (2007). Dopamine reward circuitry: two projection systems from the ventral midbrain to the nucleus accumbens-olfactory tubercle complex. Brain Res. Rev. 56, 27-78. doi: 10.1016/j.brainresrev.2007.05.004

Ince, E., Ciliax, B. J., and Levey, A. I. (1997). Differential expression of D1 and D2 dopamine and $\mathrm{m} 4$ muscarinic acetylcholine receptor proteins in identified striatonigral neurons. Synapse 27, 357-366. doi: 10.1002/(SICI)10982396(199712)27:4<357::AID-SYN9>3.0.CO;2-B

Jog, M. S., Kubota, Y., Connolly, C. I., Hillegaart, V., and Graybiel, A. M. (1999). Building neural representations of habits. Science 286, 1745-1749. doi: $10.1126 /$ science. 286.5445 .1745

Kawaguchi, Y. (1997). Neostriatal cell subtypes and their functional roles. Neurosci. Res. 27, 1-8. doi: 10.1016/S0168-0102(96)01134-0

Kelley, A. E., and Domesick, V. B. (1982). The distribution of the projection from the hippocampal formation to the nucleus accumbens in the rat: an anterograde- and retrograde-horseradish peroxidase study. Neuroscience 7, 2321-2335. doi: 10.1016/0306-4522(82)90198-1

Kelley, A. E., Domesick, V. B., and Nauta, W. J. (1982). The amygdalostriatal projection in the rat-an anatomical study by anterograde and retrograde tracing methods. Neuroscience 7, 615-630. doi: 10.1016/0306-4522(82)90067-7

Kincaid, A. E., Zheng, T., and Wilson, C. J. (1998). Connectivity and convergence of single corticostriatal axons. J. Neurosci. 18, 4722-4731.

Kreitzer, A. C. (2009). Physiology and pharmacology of striatal neurons. Annu. Rev. Neurosci. 32, 127-147. doi: 10.1146/annurev.neuro.051508.135422

Larson, E. R., and Ariano, M. A. (1994). Dopamine receptor binding on identified striatonigral neurons. Neurosci. Lett. 172, 101-106. doi: 10.1016/03043940(94)90672-6

Le Moine, C., and Bloch, B. (1995). D1 and D2 dopamine receptor gene expression in the rat striatum: sensitive cRNA probes demonstrate prominent segregation of D1 and D2 mRNAs in distinct neuronal populations of the dorsal and ventral striatum. J. Comp. Neurol. 355, 418-426. doi: 10.1002/cne.9035 50308

Lim, B. K., Huang, K. W., Grueter, B. A., Rothwell, P. E., and Malenka, R. C. (2012). Anhedonia requires MC4R-mediated synaptic adaptations in nucleus accumbens. Nature 487, 183-189. doi: 10.1038/nature11160

Mansour, A., Fox, C. A., Akil, H., and Watson, S. J. (1995). Opioid-receptor mRNA expression in the rat CNS: anatomical and functional implications. Trends Neurosci. 18, 22-29. doi: 10.1016/0166-2236(95)93946-U

Mansour, A., Fox, C. A., Burke, S., Meng, F., Thompson, R. C., Akil, H., et al. (1994). Mu, delta, and kappa opioid receptor mRNA expression in the rat CNS: an in situ hybridization study. J. Comp. Neurol. 350, 412-438. doi: 10.1002/cne.903500307

Martin, A. B., Fernandez-Espejo, E., Ferrer, B., Gorriti, M. A., Bilbao, A., Navarro, M., et al. (2008). Expression and function of CB1 receptor in the rat striatum: localization and effects on D1 and D2 dopamine receptormediated motor behaviors. Neuropsychopharmacology 33, 1667-1679. doi: 10.1038/sj.npp. 1301558

Matamales, M., Bertran-Gonzalez, J., Salomon, L., Degos, B., Deniau, J. M., Valjent, E., et al. (2009). Striatal medium-sized spiny neurons: identification by nuclear staining and study of neuronal subpopulations in BAC transgenic mice. PLoS ONE 4:e4770. doi: 10.1371/journal.pone.0004770

McGeorge, A. J., and Faull, R. L. (1989). The organization of the projection from the cerebral cortex to the striatum in the rat. Neuroscience 29, 503-537. doi: 10.1016/0306-4522(89)90128-0

Mink, J. W. (2003). The basal ganglia and involuntary movements: impaired inhibition of competing motor patterns. Arch. Neurol. 60, 1365-1368. doi: 10.1001/archneur.60.10.1365

Mogenson, G. J., Jones, D. L., and Yim, C. Y. (1980). From motivation to action: functional interface between the limbic system and the motor system. Prog. Neurobiol. 14, 69-97. doi: 10.1016/0301-0082(80) 90018-0

Monory, K., Blaudzun, H., Massa, F., Kaiser, N., Lemberger, T., Schutz, G., et al. (2007). Genetic dissection of behavioural and autonomic effects of Delta(9)-tetrahydrocannabinol in mice. PLoS Biol. 5:e269. doi: 10.1371/journal.pbio.0050269

Mulder, A. H., Wardeh, G., Hogenboom, F., and Frankhuyzen, A. L. (1984). Kappaand delta-opioid receptor agonists differentially inhibit striatal dopamine and acetylcholine release. Nature 308, 278-280. doi: 10.1038/308278a0

Perreault, M. L., Hasbi, A., Alijaniaram, M., O’Dowd, B. F., and George, S. R. (2012). Reduced striatal dopamine D1-D2 receptor heteromer expression and behavioural subsensitivity in juvenile rats. Neuroscience 225, 130-139. doi: 10.1016/j.neuroscience.2012.08.042

Perrine, S. A., Hoshaw, B. A., and Unterwald, E. M. (2006). Delta opioid receptor ligands modulate anxiety-like behaviors in the rat. Br. J. Pharmacol. 147, 864-872. doi: 10.1038/sj.bjp.0706686

Pfeiffer, A., Brantl, V., Herz, A., and Emrich, H. M. (1986). Psychotomimesis mediated by kappa opiate receptors. Science 233, 774-776. doi: 10.1126/science.3016896

Phillips, A. G., and Carr, G. D. (1987). Cognition and the basal ganglia: a possible substrate for procedural knowledge. Can. J. Neurol. Sci. 14, 381-385.

Ragnauth, A., Schuller, A., Morgan, M., Chan, J., Ogawa, S., Pintar, J., et al. (2001). Female preproenkephalin-knockout mice display altered emotional responses. Proc. Natl. Acad. Sci. U.S.A. 98, 1958-1963. doi: 10.1073/pnas.98. 4.1958

Roberts, A. J., Gold, L. H., Polis, I., McDonald, J. S., Filliol, D., Kieffer, B. L., et al. (2001). Increased ethanol self-administration in delta-opioid receptor knockout mice. Alcohol. Clin. Exp. Res. 25, 1249-1256. doi: 10.1111/j.15300277.2001.tb02344.x

Schiffmann, S. N., Jacobs, O., and Vanderhaeghen, J. J. (1991). Striatal restricted adenosine A2 receptor (RDC8) is expressed by enkephalin but not by substance P neurons: an in situ hybridization histochemistry study. J. Neurochem. 57, 1062-1067. doi: 10.1111/j.1471-4159.1991.tb08257.x

Shetreat, M. E., Lin, L., Wong, A. C., and Rayport, S. (1996). Visualization of D1 dopamine receptors on living nucleus accumbens neurons and their colocalization with D2 receptors. J. Neurochem. 66, 1475-1482. doi: 10.1046/j.14714159.1996.66041475.x

Shippenberg, T. S., Chefer, V. I., Zapata, A., and Heidbreder, C. A. (2001). Modulation of the behavioral and neurochemical effects of psychostimulants by kappa-opioid receptor systems. Ann. N. Y. Acad. Sci. 937, 50-73. doi: 10.1111/j.1749-6632.2001.tb03558.x

Shippenberg, T. S., and Herz, A. (1987). Place preference conditioning reveals the involvement of D1-dopamine receptors in the motivational properties of mu- and kappa-opioid agonists. Brain Res. 436, 169-172. doi: 10.1016/00068993(87)91571-X

Smith, Y., Bennett, B. D., Bolam, J. P., Parent, A., and Sadikot, A. F. (1994). Synaptic relationships between dopaminergic afferents and cortical or thalamic input in the sensorimotor territory of the striatum in monkey. J. Comp. Neurol. 344, 1-19. doi: 10.1002/cne.903440102

Torrecilla, M., Marker, C. L., Cintora, S. C., Stoffel, M., Williams, J. T., and Wickman, K. (2002). G-protein-gated potassium channels containing Kir3.2 and Kir3.3 subunits mediate the acute inhibitory effects of opioids on locus ceruleus neurons. J. Neurosci. 22, 4328-4334. 
Voorn, P., Vanderschuren, L. J., Groenewegen, H. J., Robbins, T. W., and Pennartz, C. M. (2004). Putting a spin on the dorsal-ventral divide of the striatum. Trends Neurosci. 27, 468-474. doi: 10.1016/j.tins.2004.06.006

Conflict of Interest Statement: The authors declare that the research was conducted in the absence of any commercial or financial relationships that could be construed as a potential conflict of interest.

Received: 18 December 2013; accepted: 10 March 2014; published online: 26 March 2014.
Citation: Oude Ophuis RJA, Boender AJ, van Rozen AJ and Adan RAH (2014) Cannabinoid, melanocortin and opioid receptor expression on DRD1 and DRD2 subpopulations in rat striatum. Front. Neuroanat. 8:14. doi: 10.3389/fnana.2014.00014 This article was submitted to the journal Frontiers in Neuroanatomy.

Copyright (c) 2014 Oude Ophuis, Boender, van Rozen and Adan. This is an openaccess article distributed under the terms of the Creative Commons Attribution License (CC BY). The use, distribution or reproduction in other forums is permitted, provided the original author(s) or licensor are credited and that the original publication in this journal is cited, in accordance with accepted academic practice. No use, distribution or reproduction is permitted which does not comply with these terms. 